\title{
Technology, Control, and the Social Organization of Work at a British Hardware Firm, 1791-1891
}

\author{
William G. Staples \\ University of California, Los Angeles
}

This paper examines the social relations of production at a British metal-trades firm throughout the 19th century. The case study reveals the existence of two distinct political apparatuses, or regimes, identified in previous literature, that govern production relations. The first regime, between 1791 and 1867 , is described as patriarchal because production is organized around adult, male, internal subcontractors and their families. In the second period, roughly 186891 , the regime is characterized as paternalistic since it attempts to align the interests of capital and worker through family, work, and community life. The analysis uncovers social and economic forces that undermined the system of internal subcontracting and patriarchy and fostered paternalism. Emerging paternalism shaped the struggles over the introduction of new technologies that formed the basis for the real subordination of labor to capital.

I told them in the afternoon that I would not have any loss of time, that if they neglected my business they might go to those who would put up with it, that I was determined I would not let them be good for nothing. . . . Some plan must be laid down and strictly adhered to to prevent the inconvenience of loss of time in the workmen: a present evil must be preferred to obviate a constant one. [ARCHIBALD KENRICK, February 7, 1787]

With those thoughts in mind, Archibald Kenrick, the first of five generations of owners of a prominent Midlands hardware firm, addressed issues

${ }^{1}$ I would like to thank Michael Burawoy, Linda Fuller, Barbara Laslett, Jon Miller, Carol Warren, and four reviewers for their criticisms and support of earlier versions. I also appreciate the assistance provided by the staffs of both the British Library and the libraries of the University of Southern California. Data for this case history were taken from R. A. Church's business case study, Kenricks in Hardware: A Family Business 1791-1966, the British Parliamentary Papers, and newspapers and industry publications in the United Kingdom. Requests for reprints should be sent to William G. Staples, Department of Sociology, University of California, Los Angeles, California 90024.

C 1987 by The University of Chicago. All rights reserved.

$0002-9602 / 88 / 9301-0003 \$ 01.50$ 
concerning the control and organization of its work force. In examining the experience of this firm over a 100-year period, I wish to illustrate how social and economic forces shaped and transformed production relations in this period of British capitalism. By making the distinction between the labor process and its mode of regulation, this case study attempts to expand the empirical basis of Burawoy's $(1983,1984)$ theoretical work on the politics of production.

Consequently, this paper sets out to achieve three goals. The first is to characterize periods of production at the firm along four dimensions: the labor process, the market structure, the reproduction of labor power, and state intervention-determinant conditions of what Burawoy (1983) has called the "factory regime." Second, I will demonstrate how these regimes shaped production politics or struggles, especially those concerning the introduction of new technologies. And finally, I will argue that the historical transformation of regimes occurs through a constellation of forces emerging from both the contradictory tendencies of capitalist development and the social relations of production.

The case-study method is particularly useful for examining, in detail, the historical transformation of the organization of work. To date, few such studies exist. The Kenrick family firm is a particularly important case since it has an extended history that is relatively well documented and spans an important period in the development of British capitalism. Moreover, as I shall illustrate, the firm eventually played a central role in a branch of Britain's metal and engineering trades by negotiating and defining industrywide arrangements concerning price structure, profits, and labor relations. My intention, however, is not to argue that this case history is necessarily representative of other firms throughout this period; in fact, the characteristics I have just cited could very well support the argument that the firm was not "average." Rather, by analyzing the Kenrick experience, I intend to provide a detailed historical account of the ways in which both capital and labor were confronted by the changing context of production and of the strategies they undertook in defending and advancing their respective positions. In doing this, I wish to illustrate a number of the theoretical concepts that have been developed in the literature and to suggest that future work incorporate a more explicit examination of the dynamics of change and the conditions and consequences of social action.

\section{THE LABOR PROCESS AND THE POLITICS OF PRODUCTION}

The Braverman-inspired debates of the past decade have produced a number of important contributions to understanding the historical transformation of work. Braverman (1974) himself attempted to link changes 
in the labor process to the structure of the marketplace during the monopoly phase of capitalism. Others have provided historical accounts of labor-control strategies (Friedman 1977; Edwards 1979; Littler 1982). Still others have focused on the social relations of production, emphasizing the generation of worker "consent" (Burawoy 1979) as well as the effect of technology (Wallace and Kallenberg 1982; Zimbalist 1979; Noble 1977, 1979).

Recent work by Burawoy $(1983,1984)$, however, has criticized laborprocess theory for its "underpoliticization" of production. Burawoy argues for a distinction between the labor process "as a particular organization of tasks" and "the political apparatuses of production conceived of as its mode of regulation" (1983, p. 589). Thus, the political regulation of production and the organization of the production or labor process may vary independently of each other. Burawoy calls these political apparatuses factory regimes and argues that they play a crucial role in the reproduction of the social relations of work and the regulation of class struggles. Through a series of historical comparisons, Burawoy (1984) attempts to show how variations in factory regimes account for the rise or fall of working-class movements by shaping interests and capacities.

Following Marx's ([1867] 1976) lead, Burawoy focuses on four crucial conditions that determine the character of the factory regime. The first is the structure of industry - the degree of competition in the marketplace. Marx argued that, during certain periods, the competitive pressures of the market threaten the very existence of a firm. Capitalists respond with the introduction of new technologies and the intensification of work. As Burawoy (1984, p. 251) put it, "Anarchy in the market leads to despotism in production: the market is constitutive of the apparatus of production."

The second condition involves the organization of work or the labor process. Here, Burawoy retains the distinction made by Marx (1976, p. 645) between the formal and the real subordination of labor to capital. Formal subordination occurs as labor is organized under one roof by capital. Capital owns the means of production, but the worker still retains control over the labor process. The real subsumption of labor follows the separation of the conception and execution of the work task by capital, and the worker becomes an objective part of production. The dependence of the worker on capital forms the third condition of the factory regime. Complete dependence implies that workers have no other means of subsistence beyond the sale of their labor; under these conditions, there is unity between the reproduction of labor power and the mode of production. Finally, Burawoy considers two forms of state intervention. Here, he distinguishes between external and internal regulation by the state. In the latter, the state regulates relations among capitalists or 
is directly involved in regulating the process of production, whereas in the former the state merely preserves the "autonomous workings of market forces" (1984, p. 252).

Burawoy contends that Marx conceived of only one prototypical regime, which Burawoy (1983) calls "market despotism." This regime highlights the condition of a competitive marketplace and is further supported by the real subordination of labor, the complete dependence of labor on capital, and exclusively external state intervention. Burawoy argues that Marx took both the complete dependence of labor and exclusively external state intervention for granted. As he states, "On examination, however, not only are they problematic, but their variation is crucial in the determination of factory regimes" $(1984$, p. 252).

Market despotism, he argues, is one particular type of factory regulation; moreover, "The four conditions of market despotism are rarely realized simultaneously. By treating them as four independent variables we can illuminate their independent effects on the form of the factory regime ..." (1984, pp. 252-53). Historical analysis (Burawoy 1984) reveals the conditions that engender different types of factory regimes and highlights the varying importance of each of the four variables for the character of a regime. For example, a patriarchal regime is associated with the conditions of market despotism, with the exception of the formal rather than the real subordination of labor, thus highlighting the importance of the labor process. Under this regime, adult male subcontractors work under one roof but retain control over the production process. Here, the family is harnessed in the factory under the control and authority of the patriarch, and direct capital involvement in the organization of production is limited (Hartmann 1976).

In contrast, under a paternalistic regime, capital is increasingly involved, both ideologically and materially, in the lives of workers. This regime underlines the importance of limited competition and is supported by the real subordination of labor and by worker dependence on one employer. Under these circumstances, employers may provide welfare benefits to workers and participate in and contribute to community projects, churches, and other institutions (Joyce 1980). This style of paternalism unites family, work, and community life and attempts to align the interests of capital and worker. Other regimes are also possible. Burawoy (1984) characterizes the factory regime of early throstle textile mills in England as a company state-a characterization that highlights the labor process and the formal subordination of labor-in which millowners dominate the entire community through political as well as economic power. Burawoy's model also permits the consideration of regimes under advanced capitalism, where consent prevails over coercion, which points 
to the importance of worker dependence on wage employment (Burawoy 1983). In these "hegemonic" factory regimes, state social insurance reduces dependence; thus new modes of factory regulation are required.

\section{CONTRADICTIONS AND THE FORCES OF CHANGE}

While Burawoy's concept of the factory regime provides an important distinction from views that focus more narrowly on the labor process, he fails to develop adequately at least one important aspect of his ideas on factory politics. His framework, presented thus far, lacks an explicit explanation for understanding the historical transformation of factory regimes.

In his analysis of early textile industries, Burawoy (1984) establishes the conditions necessary for the existence of a number of different factory regimes. Further, he attempts to link, causally, the transformation of these regimes to the four determinant conditions. He states, for example, that in Lancashire ". . . the change from the formal to the real subsumption of labor was accompanied by the concentration and centralization of capital, so that . . . we find a paternalistic regime replacing patriarchal despotism" (p. 264). Yet, what caused the change to the real subordination of labor and increased market concentration in the first place? Did these conditions form the basis of paternalism, or did paternalism provide the basis for the real subordination of labor? In essence, how do we move from one regime to the next? Although Burawoy establishes the essential conditions for the existence of factory regimes, he is less successful in explaining their transformation. His narrative alludes to a number of factors, but the forces of change are not fully drawn out.

Moreover, one consequence of "bracketing" different types of factory regimes into specific sociohistorical periods, as Burawoy has done, is that we lose the fundamentally recursive nature of social life (Giddens 1983); both the conditions for and the consequences of social action must be considered. Although the four determinant conditions shape the character of the factory regime and thereby the interests and capacities of the actors involved, such conditions are just as much an outcome of previous action as they are a circumstance of the present. By conceptualizing the conditions of regimes in more reflexive terms, we can better understand their production, reproduction, and transformation.

The position I advance here is that factory politics reflect the vestedinterest strategies of both capital and labor, and, while shaping interests and capacities, the conditions and form of the existing factory regime also reflect the cumulative effect of previous actions. Through the act of production, capital and labor produce and reproduce their own existence as well as that of capitalism itself through the application of "structural 
principles" (Giddens 1983)-the institutionalized rules and resources of recursive social practice. Yet, in this process, actors may generate or confront situations that oppose these principles of reproduction; we may consider these opposing forces as contradictions. It is within the dynamics of both social and economic contraditions that I wish to locate the transformation of factory regimes.

Marx (1976) and a number of his contemporaries (see Sweezy [1942] 1970; Mandel 1975; Wright 1978) considered contradictions and crises structural features of capitalist production; they have identified a number of these conditions. Basic contradictions emerge from both the economic and social relations of production and may occur at various levels: at the level of the state, the economy, or the firm. State intervention, often undertaken in an effort to manage crises, may be in the interests of all capitalists, in the institutional self-interest of the state (Offe 1983), or both, but may also come into conflict with the interests of individual capitalists, potentially generating new crises. Economically based contradictions include an oscillating business cycle creating overproduction, underconsumption, the centralization of capital, the destructive aspects of competition, and, if unchecked, a falling rate of profit (Marx 1976), all of which may threaten capital's ability to realize profit and engage in accumulation.

In addition to contradictions that emerge from outside the immediate sphere of production, others may develop at the level of the firm that either challenge capital's dominant position in the production process or force labor to evaluate its role in that process, bringing about struggle and change. In this case, the social relations of production come into conflict with the forces of production (i.e., the power to transform nature through labor). In summary, changes in the determinant conditions of factory regimes are the result of shifting social and economic forces that alter the context of production. The character of a particular regime reflects these changing conditions as both capital and labor confront them in pursuit of their vested interests. What follows is a comparative analysis of two production regimes in one firm in early British capitalism. This comparison reveals the role of regimes in regulating the social relations of production and illuminates the contradictions that undermined and changed the context of their existence.

THE FOUNDATIONS OF PATRIARCHY, 1791-1867

The Kenrick iron foundry dates from 1791, the year Archibald Kenrick, a plater by trade, leased a plot of land in the village of West Bromwich, outside Birmingham. The firm began producing cast-iron "odd work" for domestic consumption and commercial building, which eventually 
evolved into what was known as the hollowware trade. Traditional products of the trade included general hardware such as hinges, doorknobs, cast nails, and the like as well as domestic hollowware such as pots and pans. The production of these items required artisans to perform skilled tasks in molding, dressing, enameling, and finishing the cast hollowware.

The organization of the firm at this time was more or less typical of the Midlands metal trades (see Allen [1929] 1966), the central feature being an internal subcontracting system. In such a system, the firm's subcontractors, or "servants" as they were referred to, were paid by their employers, or "masters," according to an established price list for each piece produced. These verbal agreements stipulated that a certain number of items be produced by a specified time. These adult male contractors, in turn, hired their own workers, mostly-although not exclusively-family members or relatives, young boys and women who were paid day wages. Evidence provided to the Children's Employment Commission (Royal Commission on Children's Employment [RCCE] 1862) in 1862 indicates that, by that time, all but two of the large number of young boys at the firm were hired on this basis. The Report also provides a more detailed picture of these hiring practices and the working conditions at the foundry:

719. Charles Curley, age 10.—"Thread knuckles," i.e., put parts of hinges together, "pun" dust, take up scrap (waste metal), take out sides (of moulds), riddle sand, skim metal, i.e., take off the surface of the moulten iron from the top of the pot. . . The other younger boys do much the same. Come at 6 a.m. or a little before, and leave at $61 / 2$ or $61 / 4$ p.m. Meals in here. . . Get 3s. 4d. a week.

720. George Moore, age 9.-Am 10 next year, but don't know when. Work with father at the same work as the last boy. Was never at school except on Sunday.

721. Thomas Ferrars, age 20._"Run sides," i.e., put sand into moulds. Went to work at between 7 and 8 years old, blowing bellows and helping the man. . . Believe the queen is a woman, but do not know what her name is, or if it is Victoria.

722. James Ferrars, age 17, brother of the last witness. - Went to school last Sunday. Did not before, because I had no clothes, and never was at any school in my life, and have not been taught anything.

The commissioners added, parenthetically, that both brothers "are squalid and feeble looking; and the elder, though over 20 , looks quite a boy, and so thin that every rib could be counted, the shirt being half gone" (RCCE 1862, pp. 144-45).

The foundry was divided into uncovered, partitioned shops that housed each of the subcontractors. Early record books of the firm identified shop accounts by the name of each subcontractor: Thompson's 
Brass Shop, Steven's Shop, and the like (Church 1969). Given the existence of a dual-wage contract system, that is, the combination of both piece and day rates, the subcontractor's profit was dependent on his ability to hire the right number of assistants to complete the job and to obtain the maximum productivity from these workers. Occasionally, such a margin was not realized within the terms of the contract, and the subcontractor would have to draw on his employers to pay his workers. Accounts entitled "Workmen's Debts" appear in the early records of the firm and were, at times, substantial (Church 1969, p. 56). These debts had then to be repaid in weekly installments to the masters. Whereas some firms at this time rented space and equipment to subcontractors and may also have relied on outwork or external contracts, Kenricks exercised somewhat greater control over its work force. It did not rent space, nor did the turners pay "lathe money," the common custom of compensating employers for power and light (Allen 1966, p. 159). Thus, subcontractors at Kenricks owned no tools, equipment, or inventory.

In addition, subcontractors at the firm signed an agreement that bound them to the works for a certain period, ranging from one to five years; this restricted the easy movement from one works to the next that some master craftsmen were known for (Pollard 1968). Journeyman apprentices were similarly bound to the company rather than to contractors, and thus the firm was responsible for their training and payment. The firm deducted a specified amount from their rate of payment for tuition. Again, this practice was somewhat unusual, as most firms left this task completely to subcontractors. Thus, a relatively large number of young boys, girls, and women were paid day wages as underhands, assistants, or apprentices learning the trade under the direct supervision of adult male subcontractors working under piece arrangements (Church 1969, p. 58).

For the better part of the 19th century, the technology involved in the production of hollowware remained fairly primitive, consisting of molds and hand-held tools that aided the process of casting and dressing the product (Hawkes Smith 1838; Kenrick [1866] 1967). Steam-powered machinery was introduced at Kenricks sometime between 1805 and 1812, replacing horse-driven lathes. Continued capital expenditures occurred through the 1860s, following upswings in the business cycle, yet none of these improvements or additions to the plant and equipment had any dramatic effect on the labor process or craft skill. In fact, Kenricks engaged a number of inventors who had developed machine tools to replace manual implements. The pursuit of one such turning machine in 1841 was relinquished, however. William Kenrick explained: "The lathes used for turning hollow-ware are the ordinary round and oval lathes, the turning tool being held and directed by the workmen. Though more than 
one trial has been made to introduce a self-acting lathe for the purpose, the attempt has been abandoned on its appearing that no savings in cost could be made by the exchange of a simple lathe for the more complicated machine" (Kenrick 1967, p. 106).

Competition in the hollowware trade was relatively brisk during the first half of the 19th century, engendered by the relative ease of entry into the trade, low capital investment, and, at times, "higher than 'normal' profits" (Church 1969, p. 65). Although the specific number of firms engaged in the trades during this early period is unavailable, the evidence indicates that a number of general foundries produced various forms of hollowware (Allen 1966, pp. 20-23). By developing and adapting new techniques to improve the quality of its products and by reinvesting its profits, Kenricks grew during this time. The number of employees fluctuated between 250 and 400 , following vacillations in the economy. Overproduction produced a depression in 1830 , followed by a deflationary period that lasted, with the exception of 1836, into the 1840s (Allen 1966).

In response to this steady decline, eight of the largest firms agreed to fix prices in an effort to halt sliding profits (Church 1969, p. 66). In addition, shift work began at Kenricks in the early 1840s in the newly built enameling section of the works and was thus staffed around the clock. According to the testimony provided to the Children's Commission, this was done in order to keep the furnace alight continuously: "Three young boys from 11 or 12 upwards are employed from about nine or ten hours in attending the men" (RCCE 1862, p. 144). By the 1860s, attrition from the business cycle left only 16 firms in the area that identified themselves as makers of cast hollowware.

\section{SHAPING STRUGGLES: PATRIARCHY AND CODOMINATION, $1791-1867$}

The preceding narrative characterizes production at the firm from its inception to the 1860s, and I would now like to summarize the implications of these conditions for the politics of production. While variations in the organization of work from one firm or trade to the next existed, an important aspect of subcontracting as a general system of production was that it represented a transition from domestic to "modern" factory production. Littler (1982) argues that three types of industry-specific production relations are present in the internal-contract period and have their origins in this early period: (1) familial relations and control, (2) the role of the master craftsman and craft control, and (3) gang-boss control of work teams.

The first two of these characteristics were evident at the Kenricks firm and throughout the Midlands metal trades during this period. As the 
Children's Employment Commission reports indicate, it was not uncommon for young boys to be working alongside their fathers in the foundry. As Hartmann (1976, pp. 149-50) points out, the existing patriarchial social relations of the prefactory period were extended into the early factory, and "capitalists took advantage of this authority structure, finding women and children more vulnerable, both because of familial relations and because they were simply more desperate economically." While the contractors at Kenricks were more numerous and less powerful than some master craftsmen such as shipwrights (Pollard and Robertson 1979 , p. 164), they had considerable control of the labor process that derived from their authority and skill in their shops. Traditional patterns of production were also reflected in the workweek itself; Saturday was a half-holiday and the men "played away" on "St. Monday" or Tuesday. Thus, the workweek was often compressed into intensive three- or fourday periods, with a norm of 67.5 hours worked.

In establishing their firms, employers were able to exploit characteristics of production from the earlier domestic period and at the same time to enjoy some of the benefits of a larger production base. By engaging subcontractors, the owners were able to avoid the responsibility of organizing, supervising, and controlling the production process and to share some of the financial risks. Moreover, the fact that each subcontractor was engaged in producing different product lines and struck independent piece-rate agreements with the owners meant that the subcontractors had few common interests. This system took advantage of craft control at a time when capital was dependent on the skill of these men and their workers to produce quality goods for its markets.

In summary, Kenricks was able to secure a firm place in the Midlands hollowware trade by carrying out production under a patriarchically based factory regime (Burawoy 1984). Under this regime, although subcontractors retained control over the labor process, (1) they and their laborers had little option but to sell their labor power; there was no minimum social wage, no support from rural subsistence, and the majority of workers were subject to the family-based authority of the patriarch; (2) there was no state intervention in the form of labor legislation to protect labor from arbitrary despotism; and (3) competition led to the intensification of work and the extension of the workday.

The social relations of production involved in the piece- and day-wage internal contract system at Kenricks were reproduced by this despotic regime. Adult male subcontractors, pressured by their contractually agreed on production quotas and price lists, had to intensify both their work and their assistants' productivity in order to turn a profitespecially during deflationary periods-since piece-rate contracts did not necessarily change with economic conditions. The assistants, mostly 
young boys but some women also, were paid day wages, and hence the subcontractor had a profit incentive to "sweat" these workers with long hours and shift work. As Littler (1982, p. 78) and Hobsbawm (1964, p. 298) before him have pointed out, this system of production involved a form of codomination: between the master and subcontractor and, in turn, between the contractor and his assistants. Consequently, the system encouraged petty capitalist motivations on the part of these laboring subcontractors. The patriarchal regime of the factory provided the system of control and left the majority of workers with little choice but to engage in the process, learn the trades, and, if they were male and fortunate enough, move on to hiring their own assistants. Thus, in this period, the conditions of the factory regime permitted labor-intensification strategies in response to crises of profitability by "successfully" containing shopfloor struggles and possible resistance.

THE GENESIS OF PATERNALISM, 1868-1891

The 1860s set the stage for significant changes in the organization of work in Britain. The severe conditions of employment throughout the industrial regions became increasingly obvious (Engels [1844] 1968; Hobsbawm 1964). In particular, the treatment of children became a focal point of criticism by both the public and politicians. The general prosperity of the times provided the context for "enlightened" reforms; the metal trades, until this time free from "legislative interference," became subject to state intervention. Some of the more significant legislation having specific consequences for the trades were the Factory Acts Extension Act and the Workshops Act of $1867 .{ }^{2}$ These regulations restricted the employment of children between the ages of eight and 13 to 30 hours a week, their nocturnal employment was prohibited, and they were required to have 15 hours of schooling per week.

The tradition of family employment, so prevalent during the internalcontract period, was severely criticized by the children's commissioner in 1862; he stated that the practice, while "probably very convenient," was "very much to the prejudice of the children and young persons employed" (RCCE 1862, p. 53). The conditions of work at Kenricks appear to have been similar to those throughout the trades and were described by William Kenrick as "though often severe not injurious" (Kenrick 1967, p. 108). Yet, a factory inspector wrote in 1869 that the hollowware mills and foundries of West Bromwich (presumably including the Kenricks works) were, for the most part, dirty, ill ventilated, and "scarcely fit for anyone to work in" (Factory Inspectorate 1869, p. 271).

2 Earlier acts had restricted the employment of children in specific industries (e.g., printworks in 1845). The Extension Act of 1867 , however, restricted their employment in any manufacturing process in which 50 or more people were involved. 
Economic times were good for the hollowware manufacturers from 1869 through 1872. Production and output soared throughout the trades of the Midlands, culminating in 1872, which was described by one Birmingham paper as being "rarely equalled and never surpassed for its great and general prosperity" (Allen 1966, p. 199). William Kenrick estimated that at this time the trade employed 2,430 workers, including 1,370 men, 900 boys, and 160 women and girls and that his firm employed between one-sixth and one-quarter of the industry's work force (Kenrick 1967, p. 108). During this time, prices and wages increased as workers throughout the district began to demand-some through unionized representation (e.g., the brassworkers) - a share of the profits as well as a reduction in working hours. At Kenricks, John Arthur stated that, during this time, "The wages of half-timers have nearly doubled since the Factory Act came in, and of course all labour has gone up. We have had to increase our men's wages in some departments from 10 to 20 per cent in consequence of the great dearth of boy labour or the great prosperity of the country" (Factory and Workshops Acts Commission [FWAC] 1876, vol. 7, p. 333).

While reducing hours was resisted by many employers, others welcomed the changes, particularly in larger firms where the shortage of child labor left contractors with few options concerning their work force (Allen 1966, p. 208). They could employ continuous shifts of young workers (with considerable disruption to the work process), hire more expensive, older help, or (as John Arthur Kenrick would later testify to the commissioners) they could, as his firm had done, substitute "idiot" for child labor on the night shift (FWAC 1876, vol. 7, p. 332). Moreover, even at the cost of losing hours, a reorganization of the workweek would impart some rationality to an otherwise inefficient domestic pattern of work. A number of employers had complained in testimony to the Children's Employment Commission in 1862 that the continued observance of "St. Monday" and the like resulted in erratic work habits and production output. It was pointed out that, in one well-established firm, casters began work sometime around midday on Tuesdays (1862, p. 57). Thus, many larger employers, as well as labor, had an incentive to reorganize the workweek. Sometime in the beginning of the 1870s, the normal workweek at Kenricks became 53 hours, which was spread over five-and-ahalf days.

A price slide in the heavy industries began in 1873 , and the economic optimism of the previous few years turned to despair. By 1876, the country was in the throes of the "Great Depression," a deflationary period unparalleled in modern times (Landes 1969). Moreover, competition from American, French, and German producers challenged Britain's traditional dominance in the metal trades. In an effort to restrain competition 
among themselves, the British manufacturers came together in April of 1872 to form the Cast Iron Hollow-ware and General Iron Founders Association. With John Arthur Kenrick as chairman, the association aggressively sought to hold prices among its members. The 13 or so associate companies divided themselves into three grades of makers, Kenricks being one of two first-grade producers. These two firms controlled more than $40 \%$ of the total sales of the association. The group artificially held prices so that those of the lower grades could stay in business but not compete with the others.

The firm of Archibald Kenrick and Sons became a private limited company in August of 1883 , and, by controlling the majority of shares and dominating the board of directors, the family consolidated and formalized its control over the business. This familial control laid the basis for an increasingly paternalistic relationship with the firm's employees. The masters regularly contributed to workers' benefit clubs, hospital and pension funds, and local charities. They provided medical assistance at the works, as well as a school and library, paid compensation to victims of accidents resulting from negligence on the part of the employers, and regularly attended local community and family affairs (The Midland Chronicle and Free Press, December 10, 1943; January 28, 1944). Apprentices at the works, whose treatment the family had long prided themselves on, signed an "indenture" statement that attempted to tie their moral as well as work life to the firm. The document stated that apprentices "shall faithfully serve, their secrets kept, their lawful commands and those of their Foreman and Manager for the time being everywhere gladly do. . . . He shall not play at cards, dice tables or any other unlawful game. He shall not haunt taverns, alehouses nor absent himself from the service of the said company day or night unlawfully during the usual working hours; but in all things as a faithful Apprentice he shall behave himself to the said Company and theirs during the said term" (Church 1969, p. 284).

The usual term of the agreement was until the apprentice turned 21 years old. Furthermore, the person responsible for training the apprentice was required, "at his own proper costs," to "find and provide for the said apprentice during all the said term sufficient meat, drink, washing, medical attendance, clothing, and all other necessaries" (Church 1969, p. 284). And, as Church went on to conclude, "For absence or bad workmanship, the company retained the right to make deductions from wages, gross misconduct as defined within the terms of the indenture to be adequate grounds for dismissal without redress of payment of accrued wages" (p. 284).

Kenricks had emerged from the depths of the depression a successful and prominent institution in the community. While sales for the firm 
roughly doubled between 1870 and 1892 , the deflationary conditions of the postdepression had taken their toll; net profits as a percentage of capital employed, which had peaked in 1876 at $26 \%$, fell to less than $6 \%$ in 1886 (Church 1966, pp. 141-42). Faced with sliding profit ratios, increasing foreign competition (which threatened to disrupt the stable domestic market), an older and hence more expensive work force, and a shorter workweek, the firm found that its long-term profitability was dependent on action that would reduce operating costs. State intervention and cries of "sweating" prohibited use of the labor-intensification strategies of the past. Moreover, since the skill-based techniques involved in the production of hollowware had remained unchanged since the beginning of the century, such tasks could not be easily transferred to the semiskilled.

Confronting this dilemma, management at Kenricks sought to reduce labor costs by adopting mechanized production techniques. Despite the drain on profits, Kenrick's board of directors decided on incorporation to pursue an aggressive strategy of expansion of the company's physical plant, product diversification, and acquisition. These tactics were financed through a combination of available profits, bank loans (John Arthur Kenrick had been a member of the board of directors of Lloyds Bank since 1877), and personal savings. Between 1884 and the turn of the century, the firm nearly doubled its investment in physical plant in West Bromwich alone, and by adding new product lines and acquiring almost a dozen competitors and related companies during the period, the company diversified its production base.

The first machines adopted on a wide scale were stamping presses, which produced pan covers from a single piece of metal, with no seams. These covers were patented by Frederick Ryland, a young engineer and production supervisor at Kenricks. More significant, however, was the introduction of molding machines in the summer of 1888-again, introduced by Ryland - which were designed to cut labor and raw material costs and to produce more perfect products. Accompanying the introduction of the machinery were redundancy notices for a number of skilled workers (Church 1969, p. 87; Midland Chronicle and Free Press, July 4, 1891).

In response to these notices, the turners and tinners, subcontractors at Kenricks, demanded that those recently dismissed be reinstated and that they replace those workers since hired to work the machines. Moreover, the workers called for an increase of $15 \%$ over current prices for those working on the new machines. A week later, the employers flatly rejected the demands "in the interests of the public and the trade," stating that they could not "disguise from ourselves that the real object you have in view is to make the advantageous workings of the molding machines . . . 
impossible [and] having regard to the interest of the public and the trade, respectfully but resolutely to decline to accede to your proposals" (West Bromwich Weekly News, February 23, 1889). The evidence indicates that no further action was taken by the men and that those dismissed remained so.

Shortly after this episode, turners at Kenricks associated themselves with a more general movement of turners throughout the hollowware trade to raise and standardize piece rates and working conditions. This movement was brought about by officials of a local assembly of the Knights of Labor, an American labor organization that was attempting to organize local trades. A considerable number of Kenricks workers were said to belong to the organization, so many so that a local paper stated that the Kenricks workers constituted an entire "lodge" by themselves (West Bromwich Weekly News, February 7, 1890). The demands put forth included (1) that all employers in the United Kingdom adhere to a standard price list, (2) that the price of selling swarf (metal shavings) be raised and that the number and payment of apprentices remain in the subcontractors' control (neither had been a custom at Kenricks, however), and (3) that workmen be paid a premium for adjusting holding "chucks" on hollowware turning equipment (a task the turners had done for some time; but they now felt they deserved additional compensation for this skill).

Preliminary negotiations included the appointment of an outside arbitrator, who solicited the demands of both sides. The men submitted the above demands and a new list. The masters agreed, in principle, to the idea of a standard price list (not a specific one), but only if the turners dropped their demands concerning privileges. In April 1889, after considering the statements of both sides, the arbitrator proposed a new price list but made no mention of privileges. The list was accepted by the men's representative and was abided by for 12 months from the start of the negotiations (January 28, 1889). While not pleased with the outcome, the workmen "honorably accepted the award without solicitation," as the masters later put it to the local papers. Soon after working under the new price list, and to the astonishment of both the men and the masters, the contractors found themselves in debt. It appeared that the arbitrator's list had raised prices on certain articles of which few were manufactured and lowered prices on articles in demand. Understanding the predicament, the employers at some works forgave the debt, raised prices on certain articles, and even returned control of the swarf and apprentices to the men. This, however, contributed to even less uniformity throughout the trade, which the men saw as unfair and which had the potential of creating ill feeling among them.

In early January of 1890 , the issues were again brought to the attention 
of the masters by the men because the contracted for period was soon to expire. The turners put forth their original demands. The masters refused to consider them, suggesting that the two sides engage an arbitrator. This the men refused, citing their previous experience. Against the advice of the Knights of Labor, which called for negotiations, the turners issued a fortnight's notice to Kenricks and a dozen of the other mills in the region that, unless their demands were met, a strike would occur. Neither side conceded, and on January 30,1890, two days after the expiration of the current list, the turners struck. ${ }^{3}$

By the end of the first week of February, depleted stocks threatened to idle 3,000 workers throughout the trades. At Kenricks, 63 striking turners were able to shut down the works and place themselves and 500 of their fellow workers "at play." By the first week in March, the Cast-Iron Hollow-ware Makers Association met and agreed to "throw the doors open" on the tenth under the terms of the arbitrator's list plus $10 \%$ but stated that the swarf and apprentices belonged to the masters. None of the turners "put in an appearance," however. At Kenricks, management threatened to "give up the hollow-ware trade altogether, rather than be beaten," but they added that they would be able to do without the strikers completely in a few weeks. They were in the process of hurriedly training new turners, a decision that management claimed to regret but took "... in the interest of all our other employees" (The Birmingham Daily Gazette, March 12, 1890).

This step the turners had not anticipated. They assumed that the use of "blacklegs," or strikebreakers, would be self-defeating, as these unskilled men would spoil more work than they would finish. The employers pressed on with the trainees, however. Apparently intimidated by this development, the workers soon afterward returned to the shops and resumed production under the final terms offered by management, thus ending a five-week walkout - the first significant labor dispute in Kenricks's history. While for some men the settlement meant securing a $10 \%$ raise in current prices, for many others the raise cost privileges.

For turners at Kenricks, participation in the strike had successfully advanced their position-at least in the short term. As Church (1969, p. 291) notes, however, the lesson of their first strike was not lost on the firm's directors. Feeling that they had been placed at a considerable disadvantage by the power displayed by the turners, and in keeping with their efforts to reduce costs, the directors at Kenricks initiated plans, less than a year after the strike, to mechanize turning at the works. Frederick Ryland produced a report in December 1891 outlining the cost of the

\footnotetext{
${ }^{3}$ Details of the strike are found in the West Bromwich Weekly News and The Birming-
} ham Daily Gazette for the months January through March. 
equipment and of the compensation to those who would become redundant by both dismissals and the substitution of semiskilled females for skilled males. After a series of tests, he concluded that the machines would save an estimated $£ 4,000$ sterling a year in labor costs. Ryland had argued that, in addition to the machines, a total reorganization of the shop floor was necessary to yield optimal efficiencies. Ryland's "scientific management" perspective was apparently lost on the majority of the directors, however. Only the machines were added, and, on December 24,1891 , the notices were issued.

This time, the employers had drawn up an agreement that was first offered to the turners for their signatures, rather than simply dismissing the men. The agreement stated that "Messrs Archibald Kenrick \& Sons Ltd (hereinafter called the employers) having introduced into their works Hollow-ware turning machinery contemplate having to dismiss from their employment a considerable number of journeymen turners now employed by them in the hand turning of Hollow-ware. . . . As the necessity of dismissing their workers as above mentioned arises from no fault on the part of the workmen themselves, the Employers are desirous of making such provision as is hereinafter mentioned for any workmen who may be so dismissed so as to assist them over the time that they will be out of employ whilst seeking new engagement ..." (Church 1969, p. 291). The document went on to outline clauses that allowed compensation to as much as half an average weekly wage, for 40 weeks, to those who would be let go. The offer, considered generous by many, as well as rising prosperity throughout the region, appeared to be adequate compensation for the men. The terms of the agreement were unanimously accepted by the 68 turners, and thus the installation of hollowware turning machinery took place with little organized resistance from labor at Kenricks.

\section{SHAPING STRUGGLES: THE DECLINE OF PATRIARCHY AND THE FOUNDATIONS OF PATERNALISM, 1867-1891}

The last half of the 19th century remains a watershed in the transformation of work in Britain. Embedded in this period were the forces that would strip away the remaining vestiges of domestic production and foster the emergence of the "modern" factory. In the second period, 186791, the state intervened to restrict the employment of children and thereby shook the foundation of patriarchal control and the ties that bound the family to the workplace. By the late $1880 \mathrm{~s}$, threats to profitability forced management to seek new ways of organizing the production process, which was dominated by independent subcontractors. Capital responded with a strategy of mechanization that was aimed at 
reducing both costs and the pivotal role played by turners in the labor process.

In addition, many employers in the trades attempted to remove the traditional privileges of contractors that had laid the basis for their power and authority in the shops. Labor's skill on the shop floor, which capital had harnessed in the past, was now an obstacle to continued profitability - reflecting the contradictory tension between capital's treatment of labor as a commodity and also as a necessary source of ingenuity (Cressey and MacInnes 1980; Littler 1982). The solidarity displayed by the turners during the dramatic work stoppage of 1890 was evidence that the interdependent relationship between the masters and subcontractors was crumbling. Individual piece-rate bargaining and gentlemen's agreements became a thing of the past as the turners appeared to have realized their common interests.

How was it that Kenricks was later able to mechanize hollowware turning in the face of this potential collective interest? The answer lies in the conditions of the emerging factory regime that was undermining patriarchy, the system of subcontracting, and working-class resistance. The first condition was the change from external to internal state intervention, which removed a cheap source of labor from the subcontractors' shops. This subverted both the financial and authoritative dominance of subcontractors. The second was the market structure. Kenricks's leading position in the oligopolistic hollowware industry provided a relatively stable market and the material means for financing welfare paternalism and the change from hand to machine turning, including payment of compensation.

While profits at the firm roughly followed the oscillations of the national economy, Kenricks's owners were able to insulate themselves (through their manufacturers' association) from potentially destructive market fluctuations by regulating prices and output. From its acquisitions, the firm derived income as well as depreciation credits and an expanded sales base. This resulted in more predictable profit margins and stabler growth than if the firm had operated in a more competitive environment, and it contributed to the firm's appearance as a less risky investment when it attempted to raise capital from outside sources. Finally, subcontractors and laborers were still dependent on the sale of their labor for subsistence since no state-supported social wage existed.

Kenricks's long-standing history as a major employer in the West Bromwich area, where "generation followed generation through the works" (Church 1969, p. 58), laid the basis for the increasingly paternalistic relationship with its workers and their community. Joyce (1980) summarizes these ideological and strategic developments throughout 
British society: "The English experience of industrialism deserves to take its place in the 'golden age' of paternal, dynastic, European capitalism between 1850 and 1875. It can be argued that the English family firm of these years confronted the problem of size in a way that was more successful than variants of the military-bureaucratic model of management. ... Labour was no longer regarded as a commodity. Aiming at work and hope, the worker was appealed to as a member of the whole community, no longer isolated in the insubordination and poverty that were once taken as the mark of immorality" (1980, pp. 136-37).

It is this kind of paternalism that characterized the emerging factory regime at Kenricks. This movement reflected a distinct shift in the attitude of employers concerning the welfare of their workers. Ultimately, however, this new ideology hinged on the mutual understanding that, in exchange for welfare provisions, the company could expect loyalty and hard work from its employees. Thus, the firm could elicit considerable respect and support from the community for its actions, including mechanization, which, of course, were done in the name of good business practice. One example of this attitude was a letter from the daughter of one worker, who had been a bearer at Archibald Kenrick's funeral, to Timothy Kenrick in 1891 that summed up these feelings. The woman recalled how the elder Kenrick had visited her father, a molder, during an illness and stated that "Your grandfather was noted as a man of great perseverance in business, but never lost an opportunity of doing a good turn to his work people" (Church 1969, p. 292). ${ }^{4}$

Thus, it was in this context of "stern yet considerate paternalism founded on mutual respect" (Church 1969, p. 292) that Kenricks was able literally to "buy off" resistance by the turners, owing to a liberal compensation package and an brief upswing in the economy that buoyed the confidence of those who would be displaced and who were seeking alternative employment. (One hand turner was reported to have opened a small grocery store with his compensation, according to Church [1969, p. 292].) Moreover, the installation of turning equipment, as with the molding machines two years before, concerned only management and workers at Kenricks, unlike the work stoppage of January 1890, which affected the entire industry. Without the solidarity of turners throughout the region, Kenricks workers were undoubtedly less optimistic about successfully resisting the new technology.

In actuality, the resistance that was offered by subcontractors at Kenricks appeared less focused on the installation of specific technologies and

4 Church (1969, p. 293) also notes how, at the firm's centennial celebration held in 1891 , " . . . this paternalistic chord was struck again and again by employers, and work people" (see also Midland Chronicle and Free Press, July 4, 1891). 
more on the particular issues of job security and payment structure. For example, subcontractors voiced objection not to the introduction of molding tables in 1888 but rather to the redundancy notices handed to colleagues and demanded that those men be rehired to work the machines, with a pay increase. Again, in 1890, although the turners' collective demands focused on the conditions of work, pay, and privileges, Kenricks turners sought gains concerning only piece rates rather than the preservation of "privileges" that they had never enjoyed in the first place. These facts illustrate the generally less militant tendencies on the part of Kenricks employees and provide evidence of the power of paternalism in shaping working-class resistance and capacities.

If paternalism was such a potent force in shaping potential resistance by Kenricks workers, one might ask, How was the strike of 1890 even possible? Two points may help explain this apparent anomaly. As Church (1969, p. 289) points out, the turners may have acted more from altruism than militancy in supporting the demands of other workers in the strike of 1890 because the claims affecting the privileges of selling swarf and control over apprentices did not concern Kenricks workers. Since it was the Knights of Labor that had initiated the demands leading to the strike and since Kenricks workers were highly visible in that organization, they might have felt compelled to participate. And as Joyce (1980, p. 68) observes, even when strikes occurred during the era of paternalism, they were more passive than combative. The work stoppage of 1890 seems to have had this character. While there was definitely a dispute, hostilities were minor. A local newspaper account paraphrased the workers' spokesmen during the strike of 1890: ". . inasmuch as although the men are on strike a most friendly feeling existed between the men and their employers, and there was no desire that any unnecessary friction should be created" (Birmingham Daily Gazette, February 5, 1890).

In the end, the forces and conditions existent under the paternalistic regime proved instrumental in the demise of the system of subcontracting and its associated handicraft production. In retrospect, the resistance offered by the turners was mistakenly centered solely on payment structure. It appears that they did not see a threat from the machines (i.e., they were willing to work the machines but within the system of subcontracting, over which they had considerable control). In the end, however, it was the machines that broke subcontracting and the turners' position in it. Once installed, the turning and other mechanized production equipment had a dramatic effect on Kenricks's work force. In 1876, approximately one-third of the workers at Kenricks were young boys, women, and children. Yet, by 1894, they composed nearly 60\% (FWAC 1876, vol. 2, p. 331; Royal Commission on Labour 1892-94, vol. 7, pp. 198-99). By 1903 , there was a complete absence of hollowware turning apprentices at 
the firm. The social organization of work by the more traditional form of subcontracting had given way to direct control of piece-rate machine "operatives" by an increasing number of company foremen. As Church (1966, p. 296) notes of this trend at Kenricks, " . . the process whereby the skilled handi-craftsman retreated before the semi-skilled machine minder, was well advanced."

Thus, the real subordination of labor to capital at Kenricks, reflected in a strategy of mechanization, occurred under a paternalistic regime. This regime highlighted the condition of limited competition between firms and included both the complete separation of labor from a means of subsistence beyond the sale of their labor power and internal state intervention. These conditions shaped the struggles concerning the mechanization of hollowware in favor of capital, permitting the introduction of the new technology. In contradistinction to both Joyce (1980, p. 65) and Burawoy (1984, pp. 260-63), who argue that the bedrock of paternalism in the British textile industry was the real subordination of labor, the Kenricks case points to the possibility of just the opposite. In this instance, limited competition provided the material basis, while paternalism supplied the political foundation for the real subordination of labor.

\section{THE TRANSFORMATION OF THE FACTORY REGIME}

I have criticized Burawoy (1984) for not adequately developing his ideas concerning the historical transformation of the factory regime. What my case study illustrates is that the movement at Kenricks, from patriarchy to paternalism, and the resulting real subordination of labor to capital were engendered by a combination of economic forces and the confrontation of class interests that altered the context of production and rendered the existing technical and social organization of work obsolete. The transition is summarized in figure 1 . The diagram illustrates how the movement occurred over a period of time, and, hence, how the characteristics and conditions present in one regime overlapped the next period. That is, all four conditions did not change at one time. The year 1867 marks the beginning of the decline of patriarchy and the rise of paternalism because that was the year of internal state intervention. Thus, the character of the factory regime began to change independently of the labor process until all four determinants of paternalism were present in the year 1891 .

${ }^{5}$ Of course, some skilled occupations were created by mechanization (e.g., machine tool setters), but the net change was clearly an increase in the semiskilled. This trend occurred throughout other industries as well. E.g., as Allen notes, the percentage of semiskilled female labor in the tin-plate industry of the Midlands doubled from $18 \%$ in 1861 to $37 \%$ by 1911 (Allen 1966, p. 342). 


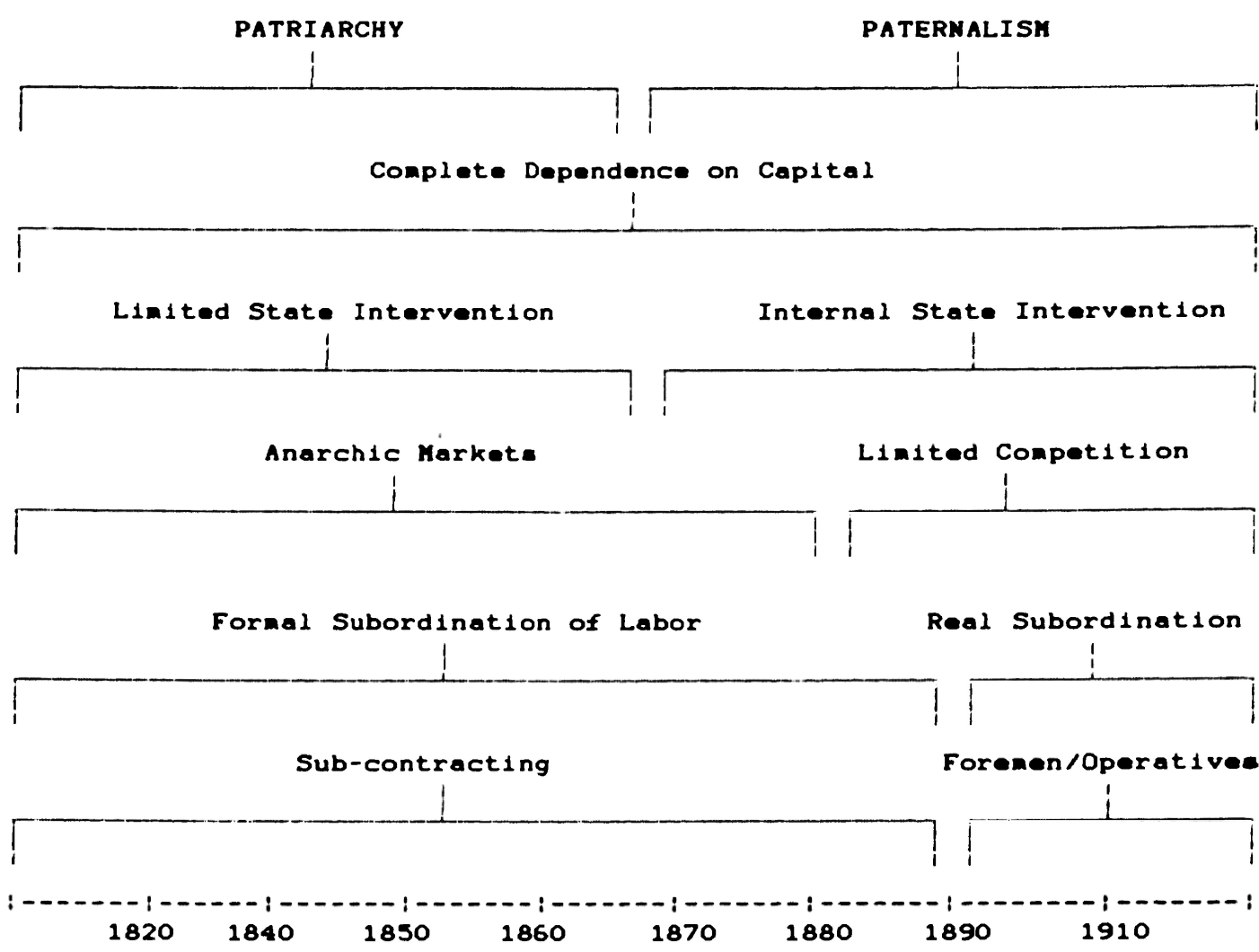

FIG. 1.-Periodization and characteristics of the factory regimes at Kenricks, 1791-1891.

The inflationary spiral of the early 1870 s saw an increase in real wages, the removal of an inexpensive pool of child labor by the state, and the establishment of a shorter workweek. These actions reflect both the concerns of the state, which was facing public criticism of the exploitation of child labor, and the general interest of all capitalists. That is, the rise in real wages boosted the purchasing power of workers at a time of overproduction as well as representing a concession by capital to the demands of labor. Moreover, the reduction in the workweek and the restriction of child labor both ensured the physical reproduction of labor power and served to quell rising criticisms of the system, thus bolstering the legitimacy of the state. However, the sheer volume of overproduction that flooded domestic markets and the rise in prices made British goods and raw materials less attractive on world markets, contributing to a dramatic price slide-the depression of 1876 . In this deflationary period, previously increased wages and fewer working hours contributed to a profit squeeze, resulting in a restriction of capital accumulation. Thus, earlier efforts to resolve the problems of overproduction, wage demands, and threatened legitimacy had the contradictory effect of contributing to a new crisis of profitability during this economic downturn. 
The severity of the downturn had a predictable effect on the already concentrated hollowware industry. Kenricks emerged from the crisis in a dominant market position, as it was able to acquire a number of its past competitors and firms in associated industries. However, the deflationary period following the depression and sliding profit ratios forced Kenricks to seek cost-cutting strategies. Given the changing context of production, however, the firm could not rely on the labor-intensification methods of the past. At this time, Kenricks turned to mechanization, a strategy it had rejected in the 1840s. In the later era, however, this approach had a number of attractive advantages: (1) it increased the productivity of labor; (2) the machines reduced the cost of labor by employing semiskilled rather than skilled labor; (3) the machines produced more perfect goods; and (4) the machines would remove the basis of the subcontractors' power in the labor process and at the bargaining table as well.

Laboring subcontractors, however, found their position in the production process threatened on all sides. The erosion of the patriarchically based contract system by the reduced participation of the family cut into the male contractors' power as well as their profit margin. They could no longer drive their workers as in the past. "Sweating" came under attack by politicians, unions, and the public. As Littler notes, "Few hands were raised to protect 'the slave-driving sub-contractor,' because new ideas, new methods, and new technology influenced employers to reach down for more control over the shop floor" (1982, p. 79).

In reaction to these pressures, subcontractors like the turners at Kenricks, encouraged by local labor groups, engaged in a strategy of work stoppages with others throughout their industry to demand wage concessions and to protest the encroachment of capital on their traditional domain. While the turners were able to draw on their pivotal role in the production process to achieve limited success with these actions, in the end, such demonstrations served only to convince capital of the necessity that it move against this potential power.

\section{CONCLUSION}

In As Sociology Meets History, Charles Tilly urges that we address a class of theoretical problems through the construction of "historically grounded accounts of collective action-in particular the conditions under which ordinary people who share an interest act, or fail to act, together on that interest. The accounts require historical grounding, most obviously, because the known means of action that are available to people (a) vary significantly as a cumulative product of historical experience; and $(b)$ strongly constrain the likelihood and the character of collective action" (1981, p. 215). By utilizing Burawoy's theoretical device, the 
factory regime, and by integrating a more theoretically explicit idea of social change, I have sought to illustrate the historical conditions that shaped and transformed production politics at Kenricks. Two particular regimes were uncovered: one was characterized by despotism and patriarchy, and the other was based on paternalism. I have argued that patriarchy and its accompanying system of subcontracting regulated and reproduced the social relations of production and that, once undermined by social and economic contradictions, this regime gave way to an emerging paternalism. This paternalism, in turn, contributed to the less militant stance of Kenricks turners, shaping the struggles over mechanization in favor of capital.

My analysis demonstrates a dynamic and flexible perspective for understanding the transformation of factory politics and changes in the labor process. This case study, as well as the work of others, highlights the considerable diversity under which the social relations of capitalist production have evolved (see Zeitlin 1979; Stone 1974; Montgomery 1979; Littler 1982). A number of authors have insisted that it is only through such detailed empirical analyses and not within "iron-law" theoretical perspectives that the complexity of workplace struggles may be revealed. This contention forces us, as Harvey (1982, p. 118) put it, " . . to reflect, once more, upon the relation between the theory of the capitalist mode of production as a whole and the historical evolution of capitalist social formations." Yet, the uneven development of capitalism does not invalidate a general theory of capitalist production and reproduction. Rather, it challenges us to understand the conditions that manifest historical diversity.

Resolving this dilemma is made easier if we accept Burawoy's argument-making the distinction between the process of production and its regulation by the conditions of the factory regime-and if we are more explicit in locating change within the dynamic of contradictions and crises endemic to a capitalist mode of production. This case study demonstrates that, within the social relations of production, both capital and labor are confronted by social and economic forces that compel action but do not determine its character. Thus, significant changes in the technical and social organization of work occur during critical historical periods in which either capital or labor is required to respond to contradictions emerging from the mode of production. While $a$ response is necessary (e.g., for capital to maintain a profit margin or for labor to maintain a living wage), the character of the specific action taken is shaped by the immediate economic and social context, that is, the conditions of the present regime. This process is both dynamic and reflexive; action changes the conditions, which, in turn, shape future action.

For example, Kenricks rejected mechanization techniques during the 
competitive and deflationary 1840 s because (1) it was dependent on craft skill for the high-quality goods it was known for-that was its competitive advantage; (2) mechanized production was expensive, and the firm lacked the material means at this time; and (3) the firm could rely on the despotic exploitation of the family under the patriarchal regime to contain the shop-floor struggles. Thus, when faced with threats to profitability, the firm could engage in labor intensification strategies that were relatively successful in increasing capital accumulation. Conditions had changed considerably, however, when the firm faced a deflationary profit squeeze in the 1880s. In this period, there was an erosion of patriarchal authority, which was undermined by state intervention, increased labor costs and restricted hours, and the threat of rising national labor organizations; all representing attempts to mediate past crises that now rendered the labor intensification strategies of the past impossible. Under these conditions, capital was forced to consider action that focused on the productivity of labor and on new methods of regulation. Limited competition, which resulted from both the centralization of capital through market dominance and the policies of a manufacturers' association, provided the foundation of paternalistic politics and regulation and the material means for capital intensive methods.

Finally, this analysis leaves us with at least two important questions: the first empirical, the second theoretical. First, in his own analysis of British cotton mills during the same historical period, Burawoy (1984) identifies patriarchal and paternalistic regimes similar to what I have described at Kenricks. What accounts for this pattern? How widespread was the emergence of paternalism in Britain at this time? Burawoy (1984, p. 263), following Joyce (1980), suggests that its appearance was contingent on the size of the employer and the community. Additional empirical analyses across different firms and industries are necessary to reveal such variation. Second, what does the historical analysis of Kenricks tell us about the relationship between market structure and the labor process? As I see the case, Kenricks's market position played a crucial role in its implementing a strategy of mechanization. Marx (1976) theorized that it would be under the competitive pressures of market despotism that mechanization would take place. Braverman (1974), however, contends that limited competition enables capital to confront the control of the labor process by the recalcitrant craft worker. Braverman was correct, at least in the Kenricks case, but, as I have argued above, the relationship goes beyond market structure and must include other determinant conditions shaping factory politics.

The rich history of the Kenrick firm provides a unique opportunity to examine the confrontation of collective interests during a crucial period of British capitalism. By taking my cue from Burawoy $(1983,1984)$ and 
distinguishing between the labor process and its regulation through political apparatuses, I have illustrated the effect of factory regimes in regulating working-class resistance. Together with other studies of other firms across different historical junctures, we can further develop an analytical framework for understanding the conditions that shape the politics of production.

\section{REFERENCES}

Allen, G. C. (1929) 1966. The Industrial Development of Birmingham and the Black Country, 1860-1927. New York: Kelley.

Braverman, H. 1974. Labor and Monopoly Capital. New York: Monthly Review. Burawoy, M. 1979. Manufacturing Consent. Chicago: University of Chicago Press. 1983. "Between the Labor Process and the State: The Changing Face of Factory Regimes under Advanced Capitalism." American Sociological Review 48:587-605.

1984. "Karl Marx and the Satanic Mills: Factory Politics under Early Capitalism in England, the United States, and Russia." American Journal of Sociology 90:247-82.

Church, R. A. 1969. Kenricks in Hardware: A Family Business 1791-1966. New York: Kelley.

Cressey, P., and J. MacInnes. 1980. "Voting for Ford: Industrial Democracy and the Control of Labour." Capital and Class 2:5-33.

Edwards, R. 1979. Contested Terrain. New York: Basic.

Engels, F. (1844) 1968. The Condition of the Working Class in England. Stanford, Calif.: Stanford University Press.

Factory and Workshop Acts Commission. 1876. Report of the Commission on the Factory and Workshops Acts. London: Her Majesty's Stationery Office.

Factory Inspectorate. Report of the Factory Inspectors. London: Her Majesty's Stationery Office.

Friedman, A. 1977. Industry and Labour. London: Macmillan.

Giddens, A. 1983. Central Problems in Social Theory. Berkeley and Los Angeles: University of California Press.

Hartmann, H. 1976. "Capitalism, Patriarchy, and Job Segregation by Sex." Pp. 13770 in Women and the Workplace, edited by M. Blaxall and B. Reagan. Chicago: University of Chicago Press.

Harvey, D. 1982. The Limits to Capital. Chicago: University of Chicago Press.

Hawkes Smith, W. 1838. Birmingham and Its Vicinity as a Manufacturing District.

Hobsbawm, E. J. 1964. Labouring Men: Studies in the History of Labour. London: Weidenfeld \& Nicolson.

Joyce, P. 1980. Work, Society and Politics: The Culture of the Factory in Later Victorian England. New Brunswick, N.J.: Rutgers University Press.

Kenrick, W. (1866) 1967. "The Hollow-ware Trade." Pp. 106-12 in Birmingham and the Midland Hardware District, edited by S. Timmins. New York: Kelley.

Landes, D. 1969. The Unbounded Prometheus: Technological Change and Industrial Development in West Europe from 1750 to the Present. Cambridge: Cambridge University Press.

Littler, C. 1982. The Development of the Labour Process in Capitalist Societies. London: Heinemann.

Mandel, E. 1975. Late Capitalism. Translated by J. De Bres. London: New Left. Marx, K. (1867) 1976. Capital, vol. 1. Harmondsworth: Penguin. 
Montgomery, D. 1979. Worker's Control in America. Cambridge: Cambridge University Press.

Noble, D. 1977. American by Design: Science, Technology and the Rise of Corporate Capitalism. New York: Knopf.

1979. "Social Choice in Machine Design: The Case of Automatically Controlled Machine Tools." Pp. 18-50 in Case Studies in the Labor Process, edited by A. Zimbalist. New York: Monthly Review.

Offe, C. 1983. Contradictions of the Welfare State. Edited by J. Keane. Cambridge, Mass.: MIT Press.

Pollard, S. 1968. The Genesis of Modern Management. Harmondsworth: Penguin.

Pollard, S., and P. Robertson. 1979. The British Shipbuilding Industry 1870-1914. Cambridge, Mass.: Harvard University Press.

Royal Commission on Children's Employment. 1862. Report of the Children's Employment Commission. London: Her Majesty's Stationery Office.

Royal Commission on Labour. 1892-94. Report of the Labour Commission. London: Her Majesty's Stationery Office.

Stone, K. 1974. "The Origin of Job Structure in the Steel Industry." Review of Radical Political Economics 6:113-73.

Sweezy, P. (1942) 1970. The Theory of Capitalist Development. New York: Monthly Review.

Tilly, C. 1981. As Sociology Meets History. New York: Academic.

Timmins, S., ed. (1866) 1967. Birmingham and the Midland Hardware District. New York: Kelley.

Wallace, M., and A. Kallenberg. 1982. "Industrial Transformation and the Decline of Craft." American Sociological Review 47:307-24.

Wright, E. O. 1978. Class, Crisis, and the State. London: New Left.

Zeitlin, J. 1979. "Craft Control and the Division of Labor: Engineers and Compositors in Britain, 1890-1930." Cambridge Journal of Economics 3:263-74.

Zimbalist, A. 1979. "Technology and the Labor Process in the Printing Industry." Pp. 103-26 in Case Studies in the Labor Process, edited by A. Zimbalist. New York: Monthly Review. 